\title{
Progressing Speaking Ability in Second Level of Elementary Education
}

\author{
Fahri TEMIZYÜREK
}

\begin{abstract}
One of the basic characteristics that makes man different from other species is absolutely man's language skill. People are able to talk, understand one another and express their feelings and ideas thanks to their language skill or they try to understand others by means of this skill. Speaking is the most influential means (way) that provide man to communicate in daily life; share his knowwledge and experiences and express his feelins, ideas, dreams and observations. While speaking, different organs work. Speaking is the skill that is fulfilled through these organs and that makes man communicate and reach an agreement with other people possible. In this research the term (phenenomenon) "speaking", the importance and the place of speaking in society and in man's life teaching of speaking skill and the things (activities) that can be done to make people acquire speaking skill have been studied.
\end{abstract}

Key Words: Turkish, speaking skill, program, training.

\section{SUMMARY} \section{Education \\ Progressing Speaking Ability in Second Level of Elementary}

Speaking, which plays an important role in individual and social life, is also one of the factors determining human success in educational and professional life. Speaking is a dimension of oral communication between individuals and is an exchange of feelings and ideas. From this point of view, speaking is a process of sharing lives between individuals. In our age, 
it is a significant factor in democratic life and is the most essential and indispensable individual right and task in a democratic society.

Speaking is very important for expressing one's thoughts. It is one of the essentials in teaching Turkish. Because speaking is the starting point of two important activities that are reading and writing. Speaking courses in educational institutions aim to make students have an ability to express their ideas and feelings in a correct and effective way in accordance with grammar rules.

Today speaking activities in schools base upon 2005 Teaching Programme on Turkish Course for Elementary Schools. This programme includes targets relating to "applying speaking rules, using voice and body language effectively, making prepared speeches, evaluating one's own speaking, gaining ability to express oneself orally".

Speaking ability is also important for communication between students and environment; cooperation; common decision; and problem solving. For this reason, teachers should make each student to speak and to take part in speaking activities individually. Educating individuals in all fields of life, who speak in a correct and effective manner and understand speeches correctly, are directly related to their success in other language abilities. In this respect, speaking ability should be supported by other abilities such as reading, writing and listening.

The most effective way to use Turkish correctly, consciously and confidently is to ask students frequently to explain their feelings orally. In order to improve speaking ability of students, teachers should make students talk about selected subjects in accordance with their levels frequently and should ask them to make peculiar critics. As the objective of Turkish course is to make students use Turkish correctly and confidently and the students imitate teachers admiringly, teachers should consider this point and pay great attention to using Turkish correctly. Also teachers should never underestimate their task of raising interest, painstaking and encouraging. Because students are more influenced by teachers' behaviours than expressions. Teachers should know that they are the most effective models for students. In this respect they should behave as the best model in all activities of Turkish course.

Turkish is a course of expression and ability more than being a course of knowledge. A good mother tongue education, carried out parallel to intellectual and mental progress of students, increases students' habit of good speaking and writing.

Within the framework of developing speaking abilities, diction studies which form physical aspect of speaking are highly emphasized. However, 
vocabulary which is directly related to speaking is the essential of speaking and is as important as speaking in a correct and good way. Vocabulary and speaking ability is more important for especially professionals such as teachers, lawyers, politicians, etc. who use language highly in their jobs.

Teachers have serious responsibilities in giving four essential language abilities. Teacher's speaking or reading is an activity of listening/comprehension for students; a student's reading or speaking is an activity of comprehension/oral composition for himself or herself and an activity of listening/comprehension for others. Starting from this point, comprehension (listening-reading) and composition (speaking-writing) should not be considered separately. 


\title{
İlköğretim İkinci Kademede Konuşma Becerisinin Geliştirilmesi
}

\author{
Fahri TEMIZYÜREK
}

ÖZ. İnsanoğlunu diğer canlılardan ayıran en temel özelliklerden birisi de şüphesiz dil becerisidir. İnsanlar dil becerileri sayesinde konuşur, anlaşır, duygu ve düşüncelerini ifade ederler ya da başkalarını bu özellikleri ile anlamaya çalışırlar. Konuşma, bireyin sosyal hayatında iletişim kurmasını, bilgi ve birikimlerini paylaşmasını; duygu, düşünce, hayal ve gözlemlerini ifade etmesini sağlayan en etkili araçtır. Konuşma sırasında çeşitli organlar görev yapmaktadır. Konuşma bu organlar yardımıyla gerçekleşen, insanın diğer insanlarla anlaşabilmesini ve iletişim kurmasını sağlayan dil becerisidir. Bu çalışmada konuşma kavramı, konuşmanın insan ve toplum hayatındaki yeri ve önemi, konuşma eğitimi ve konuşma becerisini kazandırmak için yapılabilecek etkinlikler üzerinde durulmaktadır.

Anahtar Sözcükler: Türkçe, konuşma becerisi, program, eğitim- öğretim.

\section{GíRIŞ}

İnsan, yaşamını sağlıklı ve düzenli bir şekilde sürdürebilmek için diğer insanlarla iletişim kurmak zorundadır. Çevresiyle düzenli bir iletişim kuramayan insan, zihinsel ve psikolojik özellikler bakımından normal olarak algilanmaz. En yalın anlamıyla kişiler arasında bilgi, duygu, düşünce, istek ve hayallerin aktarılması anlamına gelen iletişim, toplum içinde yaşayan insanın, kendisini doğru, güzel ve etkili bir şekilde anlatabilmesi için mutlaka gerekli olan bir süreçtir. Bu bağlamda insanın davranışları, 
konuşması, susması, duruşu, oturma biçimi, kendini ifade etme çabası ve çevresine mesaj gönderme isteği iletişimi yansıtmaktadır.

İletişim (communication) kavramı, kaynağını Latince "communis" kelimesinden almaktadır. "Communis" kelimesi de, kökeninde "common" (ortak) anlamına gelen sözü barındırır. Buna göre, insanlar arasında iletişim kurulabilmesi için ortak anlamlı sembol ve kavramların olması gerekir. Önceleri, "iletişim" ve "haberleşme" kelimeleri aynı anlamda kullanılıyordu. Ancak günümüzde iletişim kavramının boyutları, haberleşmeyi de içine alacak kadar genişlemiştir.

Sessizliği ve yalnızlı̆̆ı seçen insan, vücut diliyle, çevresine mesaj iletmeye çalışır; yani insan, sessiz kaldığı zamanlarda bile, ya vücut diliyle dışa doğru ya da otokritik yoluyla içe doğru kendisiyle iletişim hâlindedir. Kendisiyle iletişim kurduğu esnada, duygu ve düşüncelerini değerlendirir, etkileşim içine girer, kendine mesaj gönderir, onları yorumlar ve geribildirimde bulunarak inanç, tutum ve davranışlarında değişikliğe gider. $\mathrm{Bu}$ süreç, insanın iletişim kurmadan edemeyeceğini gösterir (Tutar ve Y1lmaz, 2003).

İnsanlar, tarih boyunca birbirleriyle değişik şekillerde haberleşme ve anlaşma yolları denemiş ve bu durum, farklı iletişim türlerinin doğmasını sağlamıştır. Bunlardan birisi olan sözlü iletişim, konuşma etkinliğine dayanmaktadır ve sözlü iletişimin en önemli unsuru dildir. Günlük hayatta insanlar arasındaki etkileşimlerin çoğu konuşmayla gerçekleşmektedir. Bu yönüyle dil, özellikle de konuşma dili toplumsal yaşamın temelini oluşturmaktadır.

\section{Konuşma}

İnsanı evrendeki diğer varlıklardan ayıran özelliklerin en önemlileri, düşünme gücü ve düşündüklerini ifade etme becerisidir. Konuşma yeteneği, dolayısıyla dil, insanı insan yapan niteliklerin başında gelir (Aksan, 2000). Konuşma sırasında çeşitli organlar görev yapmaktadır: Dil, diş, damak, ses teli, dudak, gırtlak ve ağız bu organlardandır. Konuşma, bu organlar yardımıyla gerçekleşen, insanın diğer insanlarla anlaşabilmesini ve haberleşmesini sağlayan bir davranış biçimidir. Konuşma zihnin, söz kalıbına döktüğü ve şekillendirdiği düşüncelerin, duyguların seslendirilmesidir. Diğer bir ifadeyle konuşma, sözlerin sesler yardımıyla ifade edilişidir.

Konuşma, sözün seslendirilmesi sırasında ortaya çıkan teknik bir boyuttur. Anlamın oluştuğu yer, söz ise; anlamın ifade edildiği kaynaktan çıkıp bir başka zihinde kendine yer bulması için ortak işaretlerin ve seslerin yardımıyla gerçekleşmesi durumuna da konuşma denilebilir (Gedizli, 2006). Ses; nefes, damak, diş, dil, geniz, girtlak ve dudaklarda biçimlenerek anlamlı birimleri oluşturur. Bu anlamlı birimin bir başka kişi tarafindan tepki alabilecek şekilde olması, konuşmanın ne olduğunu anlatan bir göstergedir. 


\section{Konuşmanın İnsan Hayath Açısından Önemi}

İnsanı insan yapan değerlerin başında bulunan, onun ruh ve beden karışımında en önemli niteliğini ortaya koyan konuşmanın, bir dile ne zaman girdiği sorusuna aranan cevaplardan elde edilen sonuçlar dikkat çekicidir. Antropolojinin linguistik dalı üzerinde çalışan bilim adamları, konuşma ile araç yapma yeteneğinin aynı zamanda ve birlikte başlamış olabileceği görüşündedir (Evliyaoğlu, 1973). İnsan zekâsının ilerlemesinde, düşüncenin, bilgilerin, bilimlerin, tekniğin, kısaca uygarlığın ve kültürün gelişmesinde başlıca etken ve araç olan konuşmanın önemi giderek artmaktadır.

Bireysel ve toplumsal hayatta önemli bir yer tutan konuşma; insanın okul ve iş hayatında başarı ya da başarısızlığını belirleyen etmenlerden de biridir. Bireyin diğer insanlarla dil yoluyla kurduğu iletişimin bir boyutunu oluşturan konuşma, bir duygu ve düşünce alışverişidir. Bu anlamıyla, bireyler arasındaki yaşantıların paylaşılması sürecidir. Çağımızda da demokratik hayatı oluşturmada bir etken olduğu gibi, demokratik bir toplumda vazgeçilmeyecek en temel bireysel hak ve görevdir.

Çocukların kazandıkları ilk dil becerilerinden biri olan konuşma, yapılan araştırmalara göre, dinlemeden sonra en çok kullanılan beceridir. Dinleme becerisinin çocuğun anne karnında başladığı, bugün somut olarak bilinen bir gerçektir. Konuşma becerisinin ise çocuğun doğumuyla beraber çıkardığı ilk seslerle başladığı kabul edilmektedir. Son yıllarda büyük yaygınlık gösteren bilgi edinme araçlarının yaptığı atılımlar sonunda, kanaatlerin oluşumunda sözlü anlatımın rolü, daha fazla olmasa da, yazılı anlatım kadar önem kazanmıştır (Marshall, 1974).

Gün içinde sabahtan akşama kadar geçen zaman dilimini düşündüğümüzde konuşmanın hayatımızda ne kadar fazla yer tuttuğu ortaya çıkacaktır. Bir an için konuşmanın hayatımızdan çıtı̆̆ını varsayalım; bu durumda, gündelik işlerimizi, ilişkilerimizi yürütmemiz hemen hemen mümkün olamayacaktı (Beyreli ve diğerleri, 2005). İnsanın başarısını, iş, eğitim ve özel hayatını büyük ölçüde etkileyen, yönlendiren faaliyet, bireyler ve birey-toplum arasında cereyan eden sözlü iletişim olarak adlandırabileceğimiz konuşmadır (Özbay, 2003).

Konuşma, insanın kendini ifade etmesi açısından çok önemli olduğu gibi, Türkçe öğretiminin de temelini oluşturmaktadır. Çünkü konuşma, okuma- yazma gibi iki önemli faaliyetin de çıkış noktasıdır. Baymur (1940: 43), sözlü ifadenin Türkçe öğretiminin temelini teşkil ettiğini şu cümlelerle ifade etmektedir: "Çocuklar için ilk ve tabiî ifade vasıtası sözdür. Sözle ifade, yetişkinlerin de en çok kullandıkları bir anlaşma vasıtasıdır. Günlük hayatta ne kadar önemli olduğunu gördügümüz sözlü ifade; imlâ, tahrir ve dil bilgisi dersleri için de temeldir. Çünkü doğru yazmak için doğru telâffuz 
önemlidir ve esastır". Özbay (2003) da konuşmanın, eğitim ve öğretim faaliyetlerinin temelinde yer aldığını, öğretmen-öğrenci arasındaki bilgi akışının; açıklama, anlatma ve değerlendirmenin en çok konuşma aracılığıyla yapıldığını vurgulamaktadır. İyi konuşan bir birey kendini tam ve doğru olarak ifade edebilir. Eğitim kurumlarında verilen konuşma derslerinin amacı, öğrencilerin düşünce ve duygularını dil kurallarına uygun, doğru ve etkili biçimde anlatma yeteneği kazandırmaya yöneliktir (Aktaş ve Gündüz, 2001).

\section{Konuşma Eğitimi}

İnsanlarla iletişim kurmanın sözlü, yazılı ve sözsüz olmak üzere değişik yolları bulunmaktadır. İnsan, çevresindeki diğer insanlarla anlaşabilmek, onlara görüş, istek, hayal vb. gibi duygu ve düşüncelerini aktarabilmek. için bu iletişim yollarından en fazla sözlü olanını yani konuşmayı kullanır. Bu sebeple toplum içinde iletişim türü olarak en fazla konuşmayı kullanan insanın, duygu ve düşüncelerini karşı taraftakilere sözlü olarak doğru, düzgün, açık ve anlaşılır bir şekilde anlatabilmesi gerekir. Doğru ve düzgün olmayan konuşma, yetersiz iletişime; yetersiz iletişim de anlama, anlatma ve anlaşma yetersizliğine; hepsi birden ise başarısızlığa neden olmaktadır (Taşer, 1982). Duygu ve düşüncelerini karşıdaki kişilere doğru ve güzel bir şekilde anlatabilmek, hem bir yetenek hem de bir beceri işidir. Bu nedenle doğru ve güzel konuşabilmek için eğitim almak ve sürekli çalışmak gerekmektedir.

Konuşma, okullarda yapılan etkinliklerin temel aracı olma özelliğini taşımaktadır. Çocuklar, okula başlamadan önce Türkçe konuşmayı ailelerinden ve yakın çevrelerinden öğrenmektedirler. Çocukların okul öncesinde öğrenmiş oldukları bu konuşma, genellikle kendi ailelerinin ve yakın çevrelerinin söyleyiş özelliklerini göstermektedir. Burada okula ve öğretmene düşen görev, çocukların yetersiz ve mahalli özellikler taşıyan konuşmalarını sabırla ve onları sıkmadan, toplumda kullanılan ortak söyleyiş ve konuşma seviyesine getirmeye çalışmaktır. $\mathrm{Bu}$ da öğrencilere doğru, düzenli ve yararlı bir konuşma eğitimi verilmesiyle gerçekleşebilir. Bugün itibariyle okullarımızda yaptırılan konuşma etkinliklerinde 2005 İlköğretim Okulları Türkçe Dersi Ögretim Programı esas alınmaktadır.

\section{5 İlköğretim Okulları Türkçe Dersi Öğretim Programında Konuşma Becerisi}

2005 Türkçe Dersi Öğretim Programı'nda konuşma becerisine yönelik ilk bilgiye programın "Giriş" bölümünde rastlanmaktadır. Bu bölümün "Genel Amaçlar" başlı̆̆ı altında bulunan şu iki maddesi konuşma becerisiyle doğrudan ilişkilidir: 
1. Öğrencilerin duygu, düşünce ve hayallerini sözlü ve yazılı olarak etkili ve anlaşılır biçimde ifade etmelerini sağlamak.

2. Öğrencilerin Türkçeyi, konuşma ve yazma kurallarına uygun olarak bilinçli, doğru ve özenli kullanmalarını sağlamak.

Konuşma becerisi, programın "Giriş" bölümündeki "Temel Beceriler" başlığı altında da anılmaktadır. Buna göre temel beceriler, öğrencilerin dil becerilerindeki gelişimleriyle bağlantılı, yatay olarak bir yılın sonunda; dikey olarak da sekizinci sinıfin sonunda kazanacakları ve hayat boyu kullanacakları temel becerilerdir. Türkçe Öğretim Programı, içerdiği kazanımlarla bu temel becerilerin gelişmesini sağlayacaktır. Programla ulaşılması beklenen temel becerilerin, konuşma ile ilgili olanları şunlardır:

- Türkçeyi doğru, güzel ve etkili kullanma

- İletişim kurma

Türkçeyi doğru, güzel ve etkili kullanmanın yazılı ve sözlü olmak üzere iki boyutu bulunmaktadır. Birey, bazen konuşma bazen yazma bazen de her iki alanı kullanarak hayatını devam ettirecektir. Programla kazandırılmak istenen diğer bir temel beceri, iletişim kurmadır. Konuşma becerisi, günlük hayatta iletişim kurma ve diğer insanlarla anlaşma bakımından çok önemli bir yer tutmaktadır. İnsanın, çevresindeki diğer insanlarla anlaşabilmesinde en büyük payı, sözlü iletişim oluşturmaktadır.

2005 Türkçe Programı'nın “Giriş” bölümünde konuşma ile ilgili olan son başl1k, "Temel Dil Becerileri"dir. Burada Türkçe eğitimi ve öğretiminin dinleme / izleme, konuşma, okuma ve yazma gibi dört temel alanından bahsedilmektedir. Bunların içinden konuşma ile ilgili olarak şu bilgilere yer verilmektedir:

Konuşma, bireyin sosyal hayatında iletişim kurmasını, bilgi ve birikimlerini paylaşmasını; duygu, düşünce, hayal ve gözlemlerini ifade etmesini sağlayan en etkili araçtır. Programda, konuşma becerisinin geliştirilmesiyle; öğrencilerin Türkçenin estetik zevkine vararak ve zengin söz varlığından faydalanarak kendilerini doğru ve rahat ifade edebilmeleri, sosyal hayatta karşılaşacakları sorunları konuşarak çözebilmeleri ve yorumlayıp değerlendirebilmeleri amaçlanmaktadır. $\mathrm{Bu}$ amaçlarla, programdaki konuşma etkinliği örneklerinde; birikimlerden, çeşitli görsel ve işitsel materyallerden yararlanma, düşüncelerini mantık akışı ve bütünlük içinde sunma, karşılaştırma yapma, sebep-sonuç ilişkisi kurma, sınıflandırma, değerlendirme ve özetleme gibi anlamayı ve zihinsel becerileri geliştirici çalışmalara yer verilmiştir.

Türkçe Öğretim Programı'nda, konuşma becerisine yönelik olarak, "konuşma kurallarını uygulama, sesini ve beden dilini etkili kullanma, 
hazırlıklı konuşmalar yapma, kendi konuşmasını değerlendirme, kendini sözlü olarak ifade etme alışkanlığı kazanma" amaçlarına yönelik kazanımlara yer verilmiştir.

Konuşma becerisi, öğrencilerin çevreleriyle iletişim kurmaları, iş birliği yapmaları, ortak karar vermeleri ve karşılaştıkları sorunları çözmeleri açısından da önemlidir. $\mathrm{Bu}$ sebeple öğretmenin konuşma etkinliklerinde öğrencilerin her birinin ayrı ayrı söz almalarını sağlayarak, onları bu çalışmalara katması gerekmektedir. Hayatın her alanında doğru, güzel, etkili konuşan ve konuşulanları doğru anlayıp yorumlayan bireylerin yetiştirilmesi, onların diğer dil becerilerinde de başarılı olmalarına bağlıdır. Bu nedenle konuşma becerisinin okuma, yazma ve dinleme gibi diğer becerilerle desteklenmesi gerekmektedir.

\section{Konuşma Eğitiminde Dikkat Edilmesi Gereken Hususlar}

Konuşma da diğer dil becerileri gibi eğitim yoluyla geliştirilebilir. Temel eğitim devresinde ciddi ve sağliklı bir konuşma eğitimi almayan kişilerin ileri yaşlarda bu becerilerinin gelişmesi de zorlaşmaktadır. Konuşma eğitiminin asıl amacı, kişinin hazırlıklı veya hazırlıksız, bir kişi veya topluluk karşısında duygu ve düşüncelerini ifade edebilmesini sağlamaktır. Konuşma eğitimi, kişinin sosyalleşmesine katkıda bulunacak şekilde verilmelidir.

Modern toplumun gerektirdiği bütün konuşma tür ve şekilleri, temel eğitimde kişilere kazandırılmalıdır. Çocuk, temel eğitimde aldığ 1 konuşma eğitimi sonunda, karşılaştığı değişik topluluklar karşısında nasıl konuşacağ konusunda eğitilmelidir. Tek ve standart bir konuşma eğitimi yerine sosyal ve yaş gruplarına göre bir konuşma eğimi verilmelidir. Gelişmiş bir dil zevkinin ve konuşma alışkanlığının kazanılmasında ferdi yeteneklerin ve sahip olunan kültürel yapının göz önünde bulundurulmasının büyük önemi vardır (Ünalan, 2000).

Çocuklar, okula başlamadan önce, iyi veya kötü bir şekilde, konuşmay1 öğrenmiş durumdadırlar. Ancak çocukların öğrendikleri bu konuşma dili, büyük oranda ailelerinin ve çevrelerinin dilinin özelliklerini yansıtır. Bu dil ayrıca öğretmenin çocukla iletişim kurma aracı olacaktır. Onun için, çocuğun bu dilinden yola çıkılmalı, zamanla çocuğun kültür diline ulaşması sağlanmalıdır (Nas, 2003).

Öğretmen, sınıf içinde, öğrencilerde görülen bireysel özelliklerin farkına varmalı; özellikle ilk yıllarda, farklı söyleyiş özelliklerine sahip olan çocuklar üzerinde, onları gerecek, sıkıntıya sokacak müdahalelerde bulunmaktan çekinmelidir. $\mathrm{Bu}$ şekilde bir müdahale, çocukların utanmalarına, çekinmelerine, arkadaşları arasında kendilerini aşağılanmış gibi hissetmelerine neden olabilir. Daha ileri aşamalarda, çocuklar kendi 
kabuklarına çekilebilir ve sınıf etkinliklerine katılmaktan kaçınabilirler. Bunu önlemek amaciyla öğretmen, kelimelerin doğru seslendirilişlerini önce kendisi göstermeli, daha sonra tüm öğrencilerin aynı anda seslendirmeyi yapmalarını sağlamalıdır. Birkaç defa yapılan tekrardan sonra öğrencilerin çok büyük bir bölümü öğretilmek istenen kelimenin doğru seslendirilişini uygulayabilecektir. Öğretmen, bu uygulamalardan sonra yanlış seslendirme ve söyleyiş özelliği gösteren öğrencilere karşı anlayışlı bir tavırla yaklaşmalı, onlara doğruyu öğrenme yolunda cesaret vermeli ve bazı konuların öğrenilmesini zamana bırakmalıdır.

Özellikle okulun ilk yıllarında karşılaşılabilecek konuşma özelliklerinden birisi de mahalli ağzın kullanılmasıdır. Diğer söyleyiş ve konuşma kusurlarının düzeltilmesi gibi mahalli ağız özelliklerinin giderilmesi için de geniş bir zamana ihtiyaç duyulmaktadır. Bu konuda da en etkili yöntem, öğretmenin standart konuşma dilini kullanarak öğrencilere model olmasıdır. Öğretmenin, hem öğrencilerle hem de okuldaki diğer öğretmen arkadaşlarıyla ortak konuşma dilini kullanarak iletişime girmesi, öğrencilerin kendi konuşmalarını düzeltmeleri için uygun bir ortam hazırlayacaktır.

Mahalli ağız özelliklerinin giderilmesinde etkili bir çalışma da öğrencilere mümkün olduğu kadar çok kitap okutmaktır. Ders kitaplarında bulunan metinlerin, kullanılan dil özelliklerine bağlı kalınarak, öğrenciler tarafından canlandırılması yoluna da gidilebilir. $\mathrm{Bu}$ çalışma, öğrencilerin, canlandırdıkları kahramanın rolüne girmelerini ve onun diliyle konuşmalarını sağlar ve bu şekilde öğrenciler kendi konuşmalarını düzeltme imkânı da bulmuş olurlar. Öğrencilerin doğru, düzgün ve etkili konuşabilmeleri için çok okumaları ve zengin bir kelime hazinesine sahip olmaları gerekmektedir. Çünkü beceriler, tekrarla kazanılır. Konuşma, eğitimle elde edilebilen bir beceridir. $\mathrm{Bu}$ beceri, elverişli ortamda uygulamayla kazanılır (Taşer, 1982). Çocuklar, ilköğretimin ilk kademesinde oldukça ileri bir konuşma becerisi kazanmış olurlar. Ancak gene de onlarda ağız özellikleri, sözcük yetersizlikleri, beceri eksiklikleri ve konuşma çekingenlikleri görülür. Öğretmen, çekingen çocukları konuşmaya isteklendirmelidir. Konuşmamak; bir bakıma düşünmemek, sonuç olarak sınıfın etkinliğine karışmamak ve öğrenmemek demektir (Kavcar ve diğerleri, 1995).

Konuşma çalışmalarına çocukların yakın çevrelerinden başlanmalı, giderek daha uzak çevrelere ait konular üzerinde konuşmalar yapılmalıdır. Bu sırada öğretmen, çocukları sabırla ve hoşgörüyle dinlemelidir. Çünkü öğrencilerin iyi birer konuşma yapabilmeleri için, söylediklerine değer verildiğini bilmeleri ve hissetmeleri gerekmektedir. Öğrencinin konuşmasi için mutlaka bir sebep bulunmalı ve buna bağlı olarak, öğrenci konuşurken ögretmen de onu anlayışla dinlemelidir. 
Türkçeyi doğru olarak, bilinçle ve güvenle kullanmayı alışkanlık hâline getirmenin en etkili yolu, derslerde öğrencilerden sık sık düşüncelerini sözlü olarak anlatmalarını istemektir. Öğretmen, bir sistem içinde seçeceği konular hakkında, seviyelerini göz önünde bulundurarak öğrencileri ne kadar çok konuşturursa, onların kendilerine özgün eleştiriler yapmalarını isterse, konuşma becerisinin gelişmesi için olumlu adımlar atmış olacaktır. Türkçe dersinin amacı, öğrencilerin Türkçeyi doğru olarak güvenle kullanmalarını sağlamak olduğundan bunu alışkanlık hâline getirmek için yoğun gayret gösterilmelidir. Öğretmenler, öğrencileri için hayranlıkla taklit edilecek birer örnek olduklarını hiçbir zaman unutmayarak, her türlü davranışta olduğu gibi, bilhassa Türkçeyi kullanmada da özen göstermelidirler (Temizyürek, 2004). Öğretmen; ilgi uyandırma, özendirme ve cesaretlendirme görevini hiçbir zaman aklından çıkarmamalıdır. Çünkü öğrenciler, öğretmenlerin dediklerinden çok yaptıklarından etkilenmektedir. Bunun için öğretmen, doğrudan doğruya kendisinin en canlı ve etkili örnek olduğunu bilmeli ve bu bilinçle, öğrencisinin karşısında Türkçe dersinin her türlü etkinliğinin en olgun modeli olarak davranmalıdır.

Türkçe, bir bilgi dersi olmaktan çok, bir ifade ve beceri dersidir. Öğrencinin zihin ve ruh gelişimiyle paralel olarak yapılan iyi bir ana dili öğretimi, çocuğun güzel konuşma ve yazma alışkanlığını geliştirecektir (Temizyürek, 2004).

Konuşma becerilerinin geliştirilmesi konusu kapsamında genellikle, konuşmanın fiziksel yönünü oluşturan diksiyon çalışmaları üzerinde durulmaktadır. Oysa konuşmanın alt yapısını, gelişmiş bir sözcük dağarcı ğı meydana getirmektedir. Bu bakımdan konuşmayla doğrudan ilişsili olan sözcük dağarcı̆̆ı, -en az- doğru ve güzel konuşma kadar önem taşımaktadır. Özellikle, işi veya mesleği gereği, dili yoğun biçimde kullanma durumunda olan öğretmen, avukat, politikacı vb. insanlar için sözcük dağarcığı ve konuşma becerisi çok daha anlamlı ve önemli bir konudur (Beyreli, 2006).

Dört temel dil becerisinin kazandırılmasında, Türkçe öğretmenlerine ve sınıf öğretmenlerine çok büyük sorumluluklar düşmektedir. Öğretmenin sınıf içindeki konuşması veya okuması, öğrenciler için dinleme / anlama etkinliği özelliği gösterirken; sınıf içinden bir öğrencinin okuması veya konuşmas1, o öğrenci için anlama / anlatma; ötekiler için ise, dinleme / anlama etkinliğidir. $\mathrm{Bu}$ gerçekten yola çıkıldığında, anlama (dinleme-okuma), anlatma (konuşma-yazma) etkinlikleri birbirinden ayrı düşünülmemelidir. 


\section{İlköğretim Okullarında Konuşma Becerisini Geliştirmek İçin Yapılabilecek Etkinlikler}

\section{Soru Sorma Alıştırmaları}

$\mathrm{Bu}$ etkinlikte herhangi bir konuya yönelik "kim, ne, neden, nas1l, nerede" gibi soru bildiren kelimelerden yola çıkılarak sorular hazırlanır. Konuşmada, doğru ve etkili soruların büyük önemi vardır. Uygun bir şekilde sorulan sorular yardımıyla hem zaman kaybından kurtulmak hem de esas konudan ayrılmamak mümkündür. Örnek:

Konu: "Umutlar Tükenmez" adlı filmin yönetmeni ile film üzerine bir konuşma.

Yönetmene sorulabilecek uygun sorular:

1. Filmin adını neden "Umutlar Tükenmez" koydunuz?

2. Filmin konusu hakkında biraz bilgi verebilir misiniz?

3. Film nerede geçiyor? Bu mekânı seçmenizin özel bir nedeni var mı?

4. Filmde yer alan oyuncular ve bu oyuncuların canlandırdıkları roller hakkında bilgi verebilir misiniz?

\section{2. "Telefon Konuşması" Alıştırmaları}

Telefon, günümüzde en yaygın olarak kullanılan haberleşme aracı durumundadır. Teknolojinin bu ürününü kullanmak, insan hayatını büyük oranda kolaylaştırmaktadır. Ancak telefonun işlevine uygun olarak kullanılması için uyulması gereken bazı kurallar vardır. Öğrencilere anlatılması ve benimsetilmesi gerekli bu kurallardan bazıları şunlardır:

- Telefonda gereksiz yere uzun süre konuşulmamalıdır.

- Telefon karşı taraftan açıldığında, arayan kişi kendini tanıtmalıdır.

- Sabah çok erken, akşam çok geç veya yemek saatleri gibi uygunsuz zamanlarda telefon edilmemelidir.

- Telefon, arayan kişi tarafindan kapatılmalıdır.

- Telefon kapatılırken verilen rahatsızlıktan dolayı özür dilenmelidir.

Aşağıda bu kurallara uygun olarak yapılan doğru bir telefon görüşmesi örneği yer almaktadır. Öğrencilerin zaman zaman bu türden etkinlikler yapmaları, teknoloji ürünlerinin nasıl kullanılması gerektiği konusunda yol gösterici olacaktır. 
Kurallara Uygun Bir Telefon Görüşmesi Örneği

(Telefon çalar.)

Filiz: Alo!..

Erkan: Merhaba Filiz! Ben, Erkan.

Filiz: Merhaba Erkan! Nasıl oldun, biraz daha iyileşebildin mi?

Erkan: İyiyim. Teşekkür ederim. Yarın okula gelebileceğim.

Filiz: Çok sevindim.

Erkan: Yarınki dersler için yapmamız gereken bir şey olup olmadığını soracaktım.

Filiz: Türkçe ders kitabından "Elveda Yıllar" adlı metni okumamız gerekiyor.

Erkan: Tamam. Teşekkür ederim. Yarın okulda görüşürüz.

Filiz: Yarın görüşmek üzere. Hoşça kal.

\section{Kendini Tanıtma Örneği}

Adım Mustafa Yuvalı.

01. 01. 1995, Ankara doğumluyum.

Annem, babam ve iki kardeşimle birlikte beş kişilik bir ailede yaşıyorum.

Kardeşlerimin isimleri Kadir ve Bengisu.

Ankara'da, Yenimahalle ilçesinde oturuyoruz.

Mehmet Akif Ersoy İlköğretim Okulu 7. sinıf öğrencisiyim.

Okulda en çok Türkçe, Matematik ve Sosyal Bilgiler derslerini seviyorum.

Okumayı çok seviyorum ve iki haftada bir kitap okuyorum.

Derslerimden arta kalan zamanlarda, arkadaşlarımla basketbol oynuyorum.

Televizyon seyretmeyi çok sevmiyorum.

Hafta sonu bağlama kurslarına devam ediyorum.

Gelecekte üniversitenin hukuk bölümünde okumak istiyorum.

\section{Bir Kişiyi Başka Bir Kişiye Tanıştırma Örneği}

Ali: Merhaba, Nurcan!

Nurcan: Merhaba, Ali! Nas1lsin?

Ali: İyiyim, teşekkür ederim. Sen nasılsın?

Nurcan: Ben de iyiyim.

Ali: Bu günlerde ne ile uğraşıyorsun? 
Nurcan: Bir ödev hazırlıyorum. Bunun için çeşitli resimler bulmam gerek, ama bilgisayarı o kadar iyi kullanamıorum.

Ali: (Hikmet'i göstererek) Seni Hikmet'le tanıştırayım o zaman.

Hikmet, eski okulumdan benim arkadaşım. (Nurcan'ı göstererek) Nurcan da komşum.

Hikmet: (Tokalaşmak için elini Nurcan'a uzatarak) Memnun oldum.

Nurcan: (Hikmet'in elini slkarak) Ben de.

Ali: Hikmet, çok iyi bilgisayar kullanır.

Nurcan: Sahi mi?

Hikmet: Yardıma ihtiyacınız olursa, haber verin. Elimden geleni yapmaya çalışırım.

Nurcan: Teşekkür ederim. Çok sevinirim.

\section{Kutlama Konuşmaları Örneği}

\section{Yeni yll kutlamasl}

Mert: Yeni yılın kutlu olsun, Aydın!

Aydın: Teşekkür ederim, Mert. Senin de yeni yılın kutlu olsun!

Mert: Umarım, yeni yılda çok mutlu olursun. Bütün dileklerine kavuşursun.

Aydın: Çok kibarsın. Dilerim, senin de yeni yılda bütün hayallerin gerçekleşir.

\section{Doğum günü kutlaması}

Aykut: Merhaba, Özge!

Özge: Merhaba, Aykut! Nasılsın?

Aykut: Teşekkür ederim, iyiyim.

Özge: Doğum günün kutlu olsun! Nice mutlu yıllara..

Aykut: Teşekkür ederim, çok naziksin.

Demirel (1999: 48-49) ve Temizyürek (2004: 2769-2783), öğrencilerin konuşma becerilerini geliştirmek için şu etkinliklerin de yaptırılabileceğini belirtmektedirler.

- Öğrencilere konuşma örnekleri göstermek ve örnek dinleme alışkanlığı kazandırmak için okulda konferanslar verdirilebilir. Ayrıca şehirde düzenlenen konferanslara öğrenciler götürülebilir. Tespit edilen bazı konuşmalar sinıfta dinletilebilir. Yine tespit edilen kimi radyo ve televizyon konuşmalarının başarılı ve başarısız yönlerini belirtmek için derslerde 15-25 
dakikalık zaman ayrılabilir. Bu uygulamalar öğrencilerin bilinçlenmelerine yardımcı olacaktır. Ayrıca okul içinde düzenlenecek bireysel ve toplu etkinliklerde (şiir dinletileri, görsel izlenceler, tartışmalar, konferanslar, sempozyumlar, münazaralar vb.) görev almaları sağlanarak öğrencilerin konuşma becerilerinin geliştirilmesine çalışılmalıdır.

- Öğrencilerin konuşma becerilerini geliştirmenin bir yolu da onlara seviyelerine uygun sorular sormaktır. Dersin öğretmenle öğrenciler arasında karşı1ıklı işlendiği düşünülürse, sorulan sorulara verilecek cevapların konuşma becerisinin gelişimine olumlu etki yapacağ 1 kesindir. Öğrencilerden alınacak cevapların doğru olup olmadığı kadar, kurulacak cümlelerin düzgün olup olmadıklarının da incelenmesi gereklidir. Onun için verilen cevapların öğretmenler tarafından yakından takip edilmesi; varsa, hataların anında düzeltilmesi gereklidir. Öğrencilerin bu sorulara "evet, öyle, hayır" gibi bir kelimelik cevap vermeleri yerine tam cümle ile cevap vermeleri sağlanmalıdır. Bunun için, kısa cevapların yanlış kabul edileceği söylenebilir.

Metin üzerinde çalışmalar yapılırken, öğrencilere değişik sorular sorularak metindeki olayın sebepleri soruşturulabilir. "Neden?, Niçin? Nasıl?" gibi sürekli sorgulamalar, düşünme yeteneğinin gelişmesine, buna bağl1 olarak da düşünceyi ifade edebilme becerisinin gelişimine büyük yararlar sağlayabilir.

- Konuşma becerilerini geliştirilebilmek için yapılacak olan faaliyetlerden birisi de anlatma çalışmalarıdır. Çocukları düzgün ve akıcı bir şekilde konuşturmak için en iyi çare onların gördükleri, yaşadıkları, duydukları, öğrendikleri, okudukları ve düşündüklerini her fırsatta serbest olarak anlatmalarına imkân vermektir. Zamanla ve yavaş yavaş dili doğru kullanmayı öğrenecek olan çocukların dili kullanma becerilerinin geliştirilmesi için nakille anlatma ve hikâye yoluyla anlatmanın yolu açılmalıdır, diyen Baymur (1940)'a hak vermek gerekir. Bu gerçekten hareketle "Anlatma çalışmalarına hangi konulardan başlanmalıdır." sorusuna cevaplar aranmalıdır.

- Cocukların konuşma yetersizliklerine dramatizasyonla da çare bulunabilir. Dramatizasyon çalışmaları çocuk kişiliğini meydana çıkarıcı olması dolayısıyla serbest konuşmaya götürücü özelliklere sahiptir. Öz'e göre; dramatizasyon uzun bir hazırlığa ihtiyaç göstermeden yapılan, dersi daha güzel ve daha anlaş1ır hâle koyan bir çalışmadır. Bunun için de bu teknikten öğretmen yeterince yararlanmalıdır (Öz, 2001). İlköğretim okullarında derslerin daha canlı hâle getirilmesinde önemli bir yeri olan dramatizasyon çalışmalarının uygulama alanı çok geniştir. Hedef kitlenin seviyesine uygun etkinlikler günlük konuşmadan, sanatsal konuşmaya kadar bütün sınıflarda uygulanarak öğrencilerin konuşma becerileri geliştirilebilir. 
Öğrencileri derse katabilmenin yollarından biri olarak da kabul edebileceğimiz bir etkinlik olan dramatizasyon çalışmaları, dersin akışında ve öğrencilerde derse karşı ilgiyi artırmada da etkili olacaktır.

- Sinıfta öğrencilerin düzeyleri ve bilgi birikimleri göz önünde bulundurularak önceden belirlenecek bir konu hakkında tartışma çalışmaları yapmak da konuşma becerisinin geliştirilmesine yönelik önemli bir etkinliktir. Bir konunun tüm yönleriyle aydınlatılması için yapılan karşılıklı konuşma olarak ifade edebileceğimiz tartışma, Türkçe derslerinde konuşma becerilerinin geliştirilmesinde kullanılmalıdır. (Öz, 2001).

- Öğrencilerin konuşma becerilerinin gelişmesi için yapılacak en önemli etkinliklerden birisi de seslerin doğru çıkarılması ve tonlamalarla vurguların yerli yerinde yapılmasıyla ilgili çalışmalardır. Bu çalışmaların önemli olduğu ve doğru yapılmadığı zaman yanlış anlaşılmaların olacağ 1 , örneklerle anlatılmalı ve ögrenciler bu konuda yetiştirilmelidir (Demirel, 1999).

- Öğrencilerin ses, vurgu ve tonlamaya yönelik eğitimlerini geliştirecek

en önemli çalışmalardan birisi de tekerlemelerin tekrarlanmasıdır. Öğretmenlerin, öğrencilerin eksik olan yönlerini tespit ettikten sonra müracaat edecekleri tekerlemeler, güzel konuşmanın vazgeçilmez materyallerindendir. Öğretmen elinde bulundurduğu tekerlemeleri yeri ve zamanı geldiğinde öğrencilere söyletme çalışması yaptırabilir. Söylenen bir tekerlemenin öğrenciler tarafindan en doğrusu söylenene kadar tekrar edilmesi çalışması yapılabilir. $\mathrm{Bu}$ çalışmada başarılı olanlar ödüllendirilebilir. Bu çalışmalar için, öğrencilerin önceden bildikleri veya ilk defa sinıfta duyacakları tekerlemelerden yararlanılabilir.

Konuşmanın zihinsel süreçlerinin geliştirilmesine yönelik olarak öğrencilere sınıflandırma, ilgilendirme ve gruplandırma çalışmaları yapılabilir. Bilginin beyinde depolanması düzensiz olursa; insanlar, konuşma esnasında bu bilgileri anında geri getirip kullanamazlar. Bu da anlatımda başarısızlığa yol açar. Sınıflandırma, bu açıdan çok önemlidir. Belleğin çalışma sistemini göz önünde bulundurarak değişik çalışmalar yapilabilir.

- Karagöz ve kukla oynatma ile de öğrencilerin konuşma becerilerini geliştirmeye yönelik çalışmalar yapılabilir. Bu etkinlik de dersin canlı hâle gelmesini sağlar. Karagöz metni, hazırlanan materyal ile birlikte öğrencilere oynattırılabilir. Bu etkinlik, orijinal metinden bağımsız olarak, öğrencilerin kendilerinin oluşturacağı bir metinle de yaptırılabilir. 


\section{SONUÇ}

Konuşma becerisi, insanın doğuştan sahip olduğu bir özellik olmakla beraber, bu becerinin geliştirilmesi insanın kendi elindedir. Örgün öğretim kurumlarında bu becerinin geliştirilmesine yönelik birtakım etkinlikler yaptırılmaktadır. Konuşma eğitiminin amacı ilköğretim programında açık bir şekilde ortaya konduğu halde, uygulamalar yetersiz kalmaktadır. Eğer uygulamalar tam yapılabilse; gençlerimiz, kendilerini ifade etmekte, sosyal etkinliklere katılmakta, fikirlerini bir bütünlük içerisinde ifade etmekte ve özgüven duygularını geliştirmekte daha başarılı olacaktır. Konuşma hayatımızın her döneminde, her türlü ortamda kullandığımız bir iletişim türüdür. Bu iletişim ne kadar sağlıklı yapılırsa toplumsal uyum ve uzlaşmayı sağlamak da o kadar kolay olacaktır. Sonuç olarak, yukarıda ifade edilmeye çalışılan etkinliklerin Türkçe öğretiminde konuşma eğitiminin önemini ortaya koyduğu ve öğrencilerin Türkçeyi doğru, akıcı, düzgün ve kurallara uygun bir şekilde öğrenmelerine katkı sağlayacağı muhakkaktır. 


\section{KAYNAKÇA}

Aksan, D. (1975). Anadili. Türk Dili, Haziran, 285.

Aktaş, Ş. ve Gündüz, O. (2001). Yazılı ve Sözlü Anlatım. Ankara: Akçă̆ Yayinlar1.

Baymur, F. (1940). Sözlü İfade. Yeni Kültür, 43-48.

Burdurlu, İ. Z. ve Kantarc1, İ. (1971). Ortaöğretimde Türkçe Öğretimi. İzmir: Karınca Matbaacılık.

Demirel, Ö. (1999). İlköğretim Okullarında Türkçe Öğretimi. İstanbul: MEB Yayınları.

Ergenç, İ. (2000). Multidisipliner Yaklaşımla Beyin ve Kognisyon: Dilin Beyindeki Organizasyonu ve Konuşmanın Gerçekleşmesi, S. Karakaş, H. Aydın, C. Erdemir ve Ç. Özemsi (Ed.) Ankara: Çizgi Tıp Yayınevi.

Evliyaoğlu, G. (1973). Konuşma Sanatt. Ankara: Gazeteciler Cemiyeti Yayınları.

Göğüş, B. (1978). Orta Dereceli Okullarımızda Türkçe ve Yazın Eğitimi. Ankara: Gül Yayınları.

İzgören M. K. (1999). Oyunlarla Dil Öğretimi. Ankara: Academyplus Yayınları.

Kavcar, C., Oğuzkan, F. ve Sever, S. (1997). Türkçe Öğretimi. Ankara: Engin Yayınları.

Marshall, J. (1994). Ana Dili ve Yazın Öğretimi. (Çev: C. Külebi). Ankara: Başak Yayıncılık.

MEB. (2005). Illköğretim Okulları Türkçe Dersi (6-8. Sinıflar) Öğretim programı. Ankara: Milli Eğitim Yayınevi.

Nas, R. (2003). Türkçe Öğretimi. Bursa: Ezgi Yayınevi.

Öz, F. (2001). Uygulamalı Türkçe Öğretimi. Ankara: Anı Yayıncılık.

Özbay, M. (2001). 0-6 Yaş Grubu Çocuklarındaki Dil Gelişiminin Türkçe Öğretimi Açısından Önemi. Bilig Dergisi, 17, 97-105.

Özbay, M. (2005). Sesle İlgili Kavramlar ve Konuşma. Milli Eğitim Dergisi, $168,116-125$.

Taşer, S. (2000). Örneklerle Konuşma Eğitimi. İstanbul: Papirüs Yayınları.

Temizyürek, F. (2004). Türkçe Öğretiminde Konuşma Eğitiminin Yeri ve Önemi. XII. Eğitim Bilimleri Kongresi'nde sunulmuş bildiriler, Gazi Üniversitesi Eğitim Bilimleri Enstitüsü. 
Temizyürek, F., Erdem, İ. ve Temizkan, M. (2007). Konuşma Eğitimi. Ankara: Öncü Yayınevi.

Tutar, H. ve Yılmaz M. K. (2003). Genel İletişim, Kavramlar ve Modeller. Ankara: Nobel Yayın Dağıtım.

Ünalan, Ş. (2003). Kişisel Gelişim Teknikleriyle Sözlü Anlatım. Ankara: Nobel Yayın Dağıtım. 